\title{
Assess the Knowledge and attitude regarding prevention of Ebola Virus among staff Nurse
}

*Mrs.Geetha $C$

\begin{abstract}
:
Objectives: To assess the level of knowledge regarding Ebola virus among staff nurses working in MGMC\&RI Hospital to assess the attitude regarding prevention of Ebola virus among staff nurses working in MGMC\&RI Hospital. To associate the knowledge and attitude on prevention of Ebola virus among staff nurses. To find out relationship between the knowledge and attitude with selective demographic variables. Methods: A quantitative approach Non-experimental descriptive design was adapted and carried out the study in MGMC \& RI Hospital at Pillaiyarkuppam, Puducherry. Results: the study findings revealed that 22 (37\%) of them have average knowledge, 50(83\%) of them had average attitude on prevention of Ebola virus. The demographic variables such as age, sex, Educational qualification, Years of experience, area of posting and Sources of health information has no significant association between knowledge and attitude on prevention of Ebola virus. Conclusion: The results shown that the staff nurses need some educational programs regarding prevention of Ebola virus.
\end{abstract}

Key wards: Prevention, Ebola virus and staff nurses.

\section{INTRODUCTION}

A virus is a small infectious agent that replicates only inside the living cells of the organisms, viruses can infect all types of life forms, from animals and plants to microorganisms including bacteria and Achaea. ${ }^{1}$

Ebola virus put humanity at a great risk we must act now and together to prevent further crisis. 9 -HailahGifty Akita

The Ebola virus belongs to a family of virus called filoviridae.
It is thought that the Ebola virus originated in the fruit bat and was introduced to human through close contact with the body fluid of infected bats. ${ }^{8}$

Infection with specific species causes Ebola virus disease (EVD). Previously known as Ebola hemorrhagic fever, EVD is a severe disease where patient suffer from fever, sore throat, muscle pain, headache, followed by nausea, vomiting, diarrhoea, decreased liver and kidney functions. ${ }^{3}$ 
Ebola virus disease first appeared in 1976 in Sudan and the democratic republic of Congo (DRC). The outbreak of the disease in the DRC was located in village near the Ebola River. ${ }^{4}$

The current outbreaks of Ebola virus disease started in guinea and it is estimated, that the first case occurred in December 2013. This outbreak is a result of the Zaire species of the Ebola virus which is the most lethal species and to the date affected the following countries: GUINEA, LIBERIA, SIERRA LEONE AND NIGERIA. As of 14th august there have been $\mathbf{1 , 9 7 5}$ suspected and confirmed cases of Ebola virus disease and 1,069 suspected deaths from Ebola virus deaths. ${ }^{6}$

The major reason why the outbreak is than previous ones in many areas, because this outbreaks has involved more urban areas also many infected patients are cared for in hospitals or at home by health care workers who do not have access to proper protective equipment such as gloves, gowns and goggles. In addition the ritual of washing decreased bodies at funerals in preparation for burial increases the amount direct contact with Ebola victims, which increases the chance of family members becoming infected. ${ }^{7}$

\section{STATEMENT OF THE PROBLEM}

A study to assess the knowledge and attitude regarding prevention of Ebola virus among staff nurses working in MGMC \& RI hospital, Puducherry.

\section{RESULTS:}

Table 1. Knowledge level of staff nurses on Ebola virus.

\begin{tabular}{|c|c|c|}
\hline Knowledge Level & Frequency & $\%$ \\
\hline Inadequate (Below 40\%) & 20 & 33.33 \\
\hline Average (40-70\%) & 22 & 36.67 \\
\hline Adequate (Above 70\%) & 18 & 30.00 \\
\hline Total & 60 & 100 \\
\hline
\end{tabular}


Table 1 depicts the knowledge level on Ebola virus among staff nurses, the results reveals inadequate, average and adequate level. In that $3=3 \%$ of respondents belongs to inadequate level, $37 \%$ respondents belongs to average level and $30 \%$ of respondents belongs to adequate level of knowledge on Ebola virus.

Table 2 . Attitude level of staff nurses on Ebola virus.

\begin{tabular}{|l|l|l|}
\hline Attitude Level & Frequency & $\%$ \\
\hline Poor (Below 40\%) & 1 & 1.67 \\
\hline Average (40-70\%) & 50 & 83.33 \\
\hline Good (Above 70\%) & 9 & 15.00 \\
\hline Total & 60 & 100 \\
\hline
\end{tabular}

Table 2 shown that the attitude level of staff nurses on Ebola virus, it reveals $2 \%$ of respondents belongs to poor attitude, $83 \%$ respondents belongs to average leve=l of attitude and $15 \%$ of respondents belongs to good attitude towards Ebola virus.

Table3. Correlation between knowledge and attitude regarding Ebola virus among staff nurse

\begin{tabular}{|c|c|c|c|c|c|c|}
\hline \multirow{2}{*}{$\begin{array}{l}\text { Knowledge } \\
\text { level }\end{array}$} & \multicolumn{3}{|c|}{ Attitude level } & \multirow[b]{2}{*}{ Total } & \multirow{2}{*}{$\begin{array}{l}\text { Chi- } \\
\text { Quire }\end{array}$} & \multirow[b]{2}{*}{ P-value } \\
\hline & Poor & Average & Good & & & \\
\hline Inadequate & 1 & 15 & 4 & 20 & \multirow{4}{*}{3.1970} & \multirow{4}{*}{0.5254} \\
\hline Average & 0 & 20 & 2 & 22 & & \\
\hline Adequate & 0 & 15 & 3 & 18 & & \\
\hline Total & 1 & 50 & 9 & 60 & & \\
\hline
\end{tabular}

Table 3 shown that the Correlation between knowledge and attitude regarding Ebola virus among staff nurses. The study findings revealed that the overall correlation between the aspects of knowledge and attitude towards Ebola virus infection. There is no correlation between the knowledge and attitude. The overall knowledge and attitude regarding Ebola virus was moderate.

\section{Association of socio-demographic variables with knowledge and attitude}

The present study revealed that is no significant association between knowledge and attitude regarding Ebola virus. Remaining variables such as age, sex, educational qualification, years of experience, area of posting, sources of health information. 


\section{RECOMMENDATIONS :}

- The study can be replicated on large sample there by findings can be generalized to a Large population. ${ }^{5}$

- Effectiveness of Information Education communication on Ebola virus for staff nurses.

- A comparative study can be conducted to assess the knowledge of Ebola virus on staff nurses and Nursing students.

\section{CONCLUSION:}

The staff nurses (37\%) where had average knowledge on Ebola virus. The staff nurses $(83 \%)$ were had average attitude regarding Ebola virus. There is no significant correlation between the knowledge and attitude towards Ebola virus. The study also suggested that specific information is to be provided to staff nurses regarding Ebola virus infection.

\section{REFERENCES:}

1.Prof. C P BAVEJA (2011), "Textbook of Microbiology for nurses", 2ND edition, Arya publishing company, page no:159.

2. DENISE F POLIT(2002), "Textbook of Nursing research", 9th edition, published by Wolters Kluwer India Pvt.Ltd., New Delhi, Page no:275

3. Bounmandouki P, Formenty $P$, EpelboinA et al. Clinical management of patients and decreased during the Ebola outbreak. December 2003; 218-223.

4. Gire SK, Goba A, Andersen KG et al. Genoic surveillance elucidates Ebola virus origin and transmission. 2014; 1369-72

5. McGuiness R. should we really be worried about the Ebola virus. July 2014; page No: 160-164.

6. Senthilingam M. Ebola outbreak: IS it time to test experimental vaccines. August 2014; page No: 62-66.

7. XuW ,Edwards MR et al. Outbreak of Ebola hemorrhagic fever. August 2014, page No: 187-200.

\section{ANSWER KEY FOR THE MONTH OF SEP - DEC 2017}

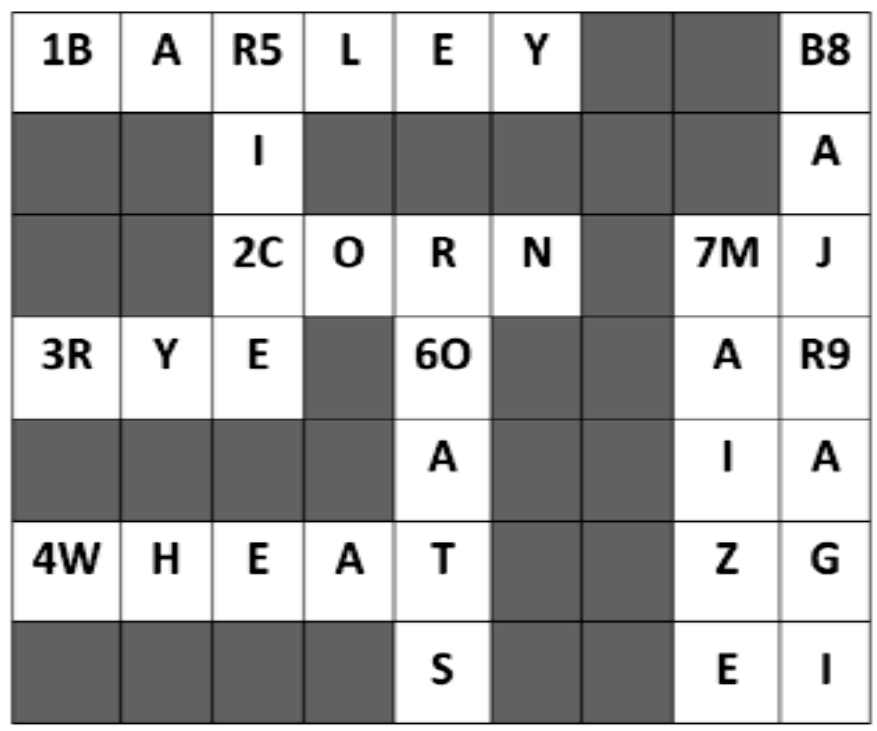

